Solid Earth, 9, 1179-1185, 2018

https://doi.org/10.5194/se-9-1179-2018

(C) Author(s) 2018. This work is distributed under

the Creative Commons Attribution 4.0 License.

\title{
Permian plume beneath Tarim from receiver functions
}

\author{
Lev Vinnik ${ }^{1}$, Yangfan Deng ${ }^{2}$, Grigoriy Kosarev $^{1}$, Sergey $_{\text {Oreshin }}{ }^{1}$, and Larissa Makeyeva ${ }^{1}$ \\ ${ }^{1}$ Institute of physics of the Earth, Russian Academy of Sciences, Moscow, Russia \\ ${ }^{2}$ State Key Laboratory of Isotope Geochemistry, Guangzhou Institute of Geochemistry, \\ Chinese Academy of Sciences, Guangzhou 510640, China
}

Correspondence: Yangfan Deng (yangfandeng@gig.ac.cn) and Lev Vinnik (vinnik@ifz.ru)

Received: 5 May 2018 - Discussion started: 25 May 2018

Revised: 20 September 2018 - Accepted: 4 October 2018 - Published: 22 October 2018

\begin{abstract}
Receiver functions for the central Tien Shan and northern Tarim in central Asia reveal a pronounced depression on the $410 \mathrm{~km}$ discontinuity beneath the Permian basalts in Tarim. The depression may be caused by elevated temperature. The striking spatial correlation between the anomaly of the MTZ and the Permian basalts suggests that both may be effects of the same plume. This relation can be reconciled with the possible motion of Tarim on the order of $1000 \mathrm{~km}$ by assuming that the mantle layer, which has moved coherently with the plate since the Permian, extends to a depth of $410 \mathrm{~km}$ or more. Alternatively, the lithosphere and underlying mantle are decoupled at a depth of $\sim 200 \mathrm{~km}$, but a cumulative effect of the Tarim plate motion since the Permian is less by an order of magnitude. A similar explanation is applicable to the Siberian traps.
\end{abstract}

\section{Introduction}

The rigid lithosphere and the underlying ductile upper mantle (asthenosphere) should be decoupled at the lithosphereasthenosphere boundary (Eaton et al., 2009). The depth to the lithosphere-asthenosphere boundary (LAB) ranges from a few tens of kilometers for a young lithosphere to about $300 \mathrm{~km}$ for Precambrian cratons (e.g., Artemieva and Mooney, 2001). Another idea postulates that the layer that translates coherently with the continental plate (tectosphere) may extend to a depth of at least $400 \mathrm{~km}$ (Jordan, 1978). The tectosphere is stabilized against convective disruption by depletion in the basalt-like component. Examples of the successful application of the concept of a deep tectosphere to geophysical data are few. We test this idea by comparing the locations of possible remnants of extinct mantle plumes in the mantle transition zone (MTZ) and the related basaltic outcrops at the Earth's surface.

Recently this test was applied to the mantle beneath the Siberian traps (Vinnik et al., 2017). These traps present the result of gigantic basalt eruptions that took place near the Permian-Triassic boundary at about $250 \mathrm{Ma}$ (Fedorenko et al., 1996). The analysis of the structure of the mantle was conducted with the aid of receiver function techniques that were applied to the recordings of seismograph station Norilsk (NRIL) in the north of the Siberian large igneous province (LIP). In the vicinity of NRIL, the thickness of the traps is maximal (in a range of a few kilometers). This analysis has shown that the seismic boundary at the top of the MTZ with a standard depth of $410 \mathrm{~km}$ is depressed in the vicinity of NRIL by $10 \mathrm{~km}$. The diagram of olivine-wadsleyite phase transition may account for this depression by assuming an approximate $100 \mathrm{~K}$ increase in temperature.

In the depth range from 350 to $410 \mathrm{~km}$, the $\mathrm{S}$ velocity beneath the Siberian traps is reduced by $4-5 \%$ (Vinnik and Farra, 2007) relative to the IASP91 model (Kennett and Engdahl, 1991). This is a likely effect of about $1 \mathrm{vol} \%$ or more melt (Hier-Majumder and Courtier, 2011), which is unusual for cratons. Another low-velocity layer is found in the depth interval from 460 to $500 \mathrm{~km}$. A similar anomaly was found in the vicinities of several hot spots (e.g., Vinnik et al., 2012). The low S-wave velocity coincides in depth with the abrupt decrease in the solidus temperature of carbonated mantle (Keshav et al., 2011) and may also be related to melting.

The present day coordinates for the center of the Siberian traps are $65.0^{\circ} \mathrm{N}, 97.0^{\circ} \mathrm{E}$. The estimated coordinates for the reconstructed eruption center are $57.7^{\circ} \mathrm{N}, 54.7^{\circ} \mathrm{E}$ (Torsvik et al., 2008). This means the lithosphere underlying the Siberian traps moved in the last $250 \mathrm{Myr}$ by about $2000 \mathrm{~km}$ 
to the northeast-east (Torsvik et al., 2008). The anomalies of the MTZ might preserve their position beneath the Siberian traps in spite of the plate motion if they moved coherently with the plate.

A similar conclusion is obtained for Greenland by Kraft et al. (2018). Arrival times of P660s and P410s modeconverted phases in $\mathrm{P}$ receiver functions (PRFs) were measured at 24 seismograph stations in central-eastern Greenland. In two regions corresponding to basaltic outcrops about 55 Myr old, the differential time between P660s and P410s seismic phases is reduced by more than $2 \mathrm{~s}$ relative to the IASP91 reference model. The $410 \mathrm{~km}$ discontinuity in these regions is depressed by more than $20 \mathrm{~km}$. Kraft et al. (2018) interpret this as due to elevated temperature. The basaltic outcrops and the related temperature anomalies may be related to the passage of Greenland over the Iceland hot spot. This explanation is consistent with the concept of a deep tectosphere and implies that the upper mantle beneath Greenland to a depth of at least $400 \mathrm{~km}$ translates coherently with the Greenland plate.

Here we describe a similar analysis for the central Tien Shan and Tarim in central Asia and discuss the possible implications of these observations.

\section{Seismic structure of the MTZ beneath the central Tien Shan and Tarim}

This section presents in condensed form the results of the recent seismic study (Kosarev et al., 2018) of the MTZ beneath the central Tien Shan and northern Tarim (Fig. 1). The ongoing orogenesis in central Asia is likely a far-field effect of the India-Eurasia collision (Molnar and Tapponnier, 1975). Previous mountain-building episodes in the region of the Tien Shan took place in the Paleozoic (e.g., Windley et al., 1990), but for at least $100 \mathrm{Myr}$ prior to the onset of the present day mountain building the lithosphere of the Tien Shan was quiet. Tectonic activity resumed at about 25-20 Ma in the southern Tien Shan (Sobel and Dumitru, 1997) and at $11 \mathrm{Ma}$ in the north (Bullen et al., 2001). The lithosphere of Tarim underthrusts the relatively weak lithosphere of the Tien Shan at a rate of about $20 \mathrm{~mm} \mathrm{yr}^{-1}$ (Reigber et al., 2001).

The seismograph network in Fig. 1 is composed of several networks. The largest networks are CHENGIZ, MANAS, KNET, KRNET, and KZ. CHEGIS and MANAS were deployed for 1.5-2 years. KNET, KZ, and KRNET are practically permanent. As the MANAS network is very dense relative to the others, the MANAS stations were divided into clusters of four neighboring stations and each cluster was replaced by one station with a reduced number of recordings. Seismic events of sufficient magnitude (5.5 and more) in a distance range from 35 to $90^{\circ}$ are abundant in a broad azimuth range (Fig. 2a).

The recordings of 64 broadband stations in Fig. 1 were low-pass filtered with a corner at $6 \mathrm{~s}$ and transformed into

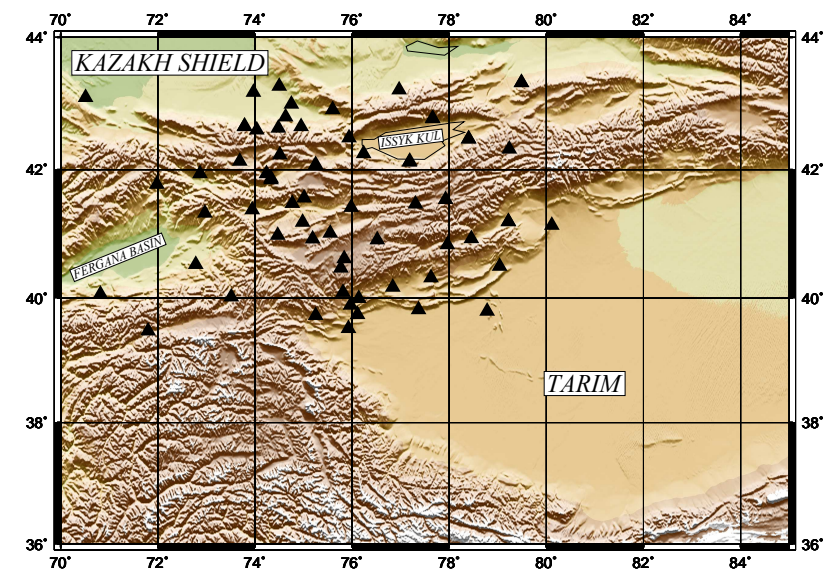

Figure 1. Topographic map of the study region and the seismograph network.

PRFs. The PRFs were calculated by using the $L Q$ coordinate system, where $L$ is parallel to the principal motion direction of the $\mathrm{P}$ wave and $Q$ is normal to $L$ in the wave propagation plane. The $Q$ components were deconvolved by the $L$ components in the time domain. The individual PRFs were visually inspected and those with a relatively low noise were stacked. The low-noise PRFs present on the average about $50 \%$ of all inspected PRFs.

In the context of our study the most important elements of the stacked PRFs are P660s and P410s mode-converted seismic phases. The 410 and $660 \mathrm{~km}$ discontinuities mark the top and bottom of the MTZ, and their depths are sensitive to temperature and composition. The times of P660s and $\mathrm{P} 410$ s seismic phases depend not only on the topography of the 660 and $410 \mathrm{~km}$ discontinuities, but also on volumetric velocity heterogeneities above the $410 \mathrm{~km}$ boundary. Separation of these two effects is the main problem of interpreting the observations of P660s and P410s phases. This problem is solved by calculating the time difference (differential time) between the arrivals of P660s and P410s phases. The ray paths of P660s and P410s phases in the crust and upper mantle are close to each other for the same seismic recording, and, as a result, the differential time is insensitive to the properties of the Earth's medium above the MTZ.

One possibility to map the differential time is to apply a version of common conversion point (CCP) stacking: to divide the Earth's surface into cells and to stack, after appropriate move-out corrections, the PRFs, of which the projections of the conversion points fall into the same cell. However, the surface projections of the conversion points of P410s and P660s phases for the same recording are at different distances (around 1 and $2^{\circ}$, respectively) from the seismograph station, and the set of PRFs thus selected for the detection of the $\mathrm{P} 410$ s phase may differ from that for the P660s phase. Then the differential time of stacked P660s and P410s phases can be affected by lateral heterogeneity of the crust and mantle 


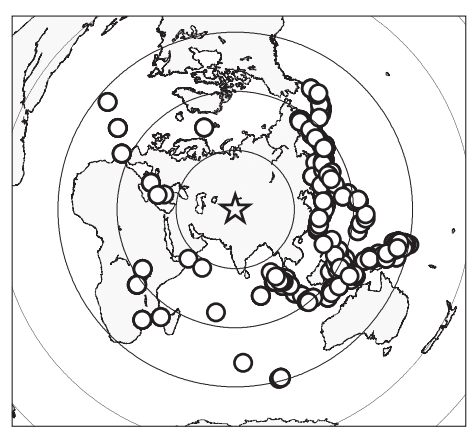

(a)

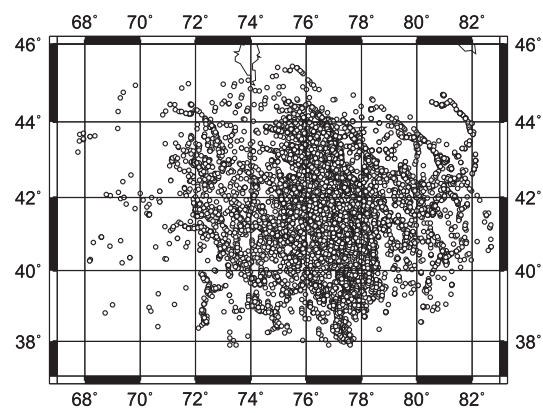

(b)

Figure 2. Epicenters of seismic events (a) and projections of piercing points at a depth of $535 \mathrm{~km}$ (b).

above the MTZ. This can be avoided by locating the conversion points in the middle of the MTZ (at a depth of $535 \mathrm{~km}$ ) and stacking those PRFs, the conversion point projections of which are located within the same cell. Then the P410s and P660s phases for each cell are detected in the same set of PRFs and the effect of lateral heterogeneity above the $410 \mathrm{~km}$ discontinuity is minimized.

The offset of $1^{\circ}$ of the projections of the P660s and $\mathrm{P} 410$ s piercing points may distort the stack, but this effect is strongly reduced by stacking PRFs in opposite back azimuths. The effect of the offset disappears completely if one discontinuity ( 660 or $410 \mathrm{~km}$ ) is flat. This is characteristic of subregions B and C (see the rest of this section).

We neglect velocity heterogeneities extending through the MTZ because for a realistic temperature anomaly of $100 \mathrm{~K}$ the related time residual of P660s in the MTZ is around $0.2 \mathrm{~s}$ (e.g., Shen et al., 2002). The residuals that are accumulated in the crust and upper mantle above the $410 \mathrm{~km}$ discontinuity are usually much larger. The average residual for the crust and upper mantle of the Tien Shan is $0.6 \mathrm{~s}$ (see the rest of this section).

Surface projections of the conversion points at a depth of $535 \mathrm{~km}$ cover the area between 38 and $44^{\circ} \mathrm{N}$ and between 72 and $82^{\circ} \mathrm{E}$ (Fig. 2b). The conversion points were calculated by using the IASP91 model. 3-D tomographic models (Lei and Zhao, 2007; Li et al., 2009; Zabelina et al., 2013) were not used for ray tracing because they represent only the central part of the study region and differ in details. On the other hand, the IASP91 model is simple, robust, and sufficiently accurate for our task. The cells were chosen in the form of a rectangular box. The optimum size of the box was found through trial and error. If the box is too small, we cannot find a sufficient number of receiver functions with piercing points within the box. If the box is too large, the travel time anomalies of P410s and P660s may be lost because of smoothing. The optimum size $\left(2^{\circ}\right.$ for NS and EW or 220 and $160 \mathrm{~km}$, respectively) provides a reasonable compromise.

The largest number of stacked PRFs exceeds 1750, and the smallest is 48 . These numbers are sufficient for a robust detection of P660s and P410s phases (see example in Fig. 3, in which the number of stacked PRFs is 48). The move-out corrections for stacking are calculated for different assumed depths of conversion in a range from 0 to $800 \mathrm{~km}$. If the move-outs are free from significant artifacts, the maximum amplitudes of the P410s or P660s phases are observed in the traces corresponding to depths that are close to 410 or $660 \mathrm{~km}$. This is evident in Fig. 3. The accuracy of the estimates of the differential time (confidence interval of $66 \%$ ), which was determined by bootstrap resampling (Efron and Tibshirani, 1991), is typically $0.2 \mathrm{~s}$.

For most boxes the residuals of the differential time with respect to the IASP91 value (23.9 s) are on the order of a fraction of a second (Fig. 4). Large residuals (more than $1.0 \mathrm{~s}$ ) are obtained for three boxes: $\left(40-42^{\circ} \mathrm{N}, 76-78^{\circ} \mathrm{E},+1.5 \mathrm{~s}\right),(40$ $\left.42^{\circ} \mathrm{N}, 72-74^{\circ} \mathrm{E},-1.1 \mathrm{~s}\right)$, and $\left(38-40^{\circ} \mathrm{N}, 80-82^{\circ} \mathrm{E},-1.5 \mathrm{~s}\right)$. Further on these boxes are referred to as A, B, and C. For the IASP91 velocities the resulting thickness anomalies of the MTZ in A, B, and C are $+15,-11$, and $-15 \mathrm{~km}$, respectively. These anomalies are located beneath the southcentral Tien Shan, Fergana Basin, and Tarim. While the number of stacked PRFs for C is minimal (48), the quality of the PRFs (signal-to-noise ratio) in this box is very high and the stack (Fig. 3) is comparable in quality with those in the other boxes.

Beyond the differential time, the analysis involves an evaluation of the topography of the 410 and $660 \mathrm{~km}$ discontinuities. The P410s and P660s phases propagate within the crust and upper mantle only in the nearest vicinities of the seismograph stations. These stations are usually located outside the related box (see Kosarev et al., 2018) and spread in the region that is comparable in dimension with the station network. Therefore the residuals that are accumulated at shallow depths and observed in a certain box may be close to the average residual for the station network. In the estimates of the average residuals the data from the three anomalous boxes $\mathrm{A}, \mathrm{B}$, and $\mathrm{C}$ are excluded. The average residuals thus obtained are $+0.5 \pm 0.3 \mathrm{~s}$ for P410s and $+0.7 \pm 0.4 \mathrm{~s}$ for P660s. Both estimates are close and the value adopted for further calculations is $+0.6 \pm 0.3 \mathrm{~s}$. After the removal of this residual from the observed travel times, for the anomalous box 


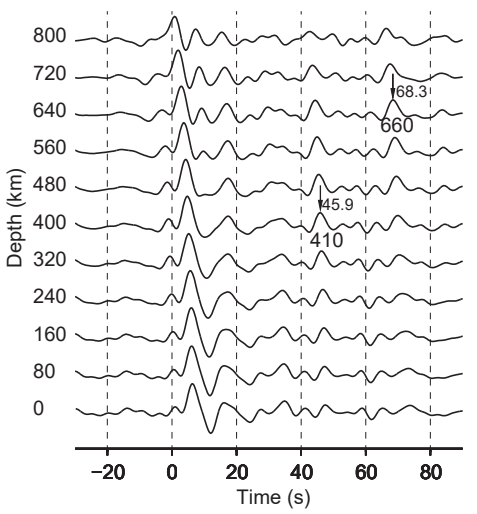

Figure 3. Stacked PRFs for the box with the corners at $38-40^{\circ} \mathrm{N}$ and $80-82^{\circ}$ E. Move-out corrections for stacking are calculated for depth (in $\mathrm{km}$ ) attached to the traces on the left-hand side. The detected P410s and P660s phases are marked by arrows. Note that the largest amplitudes of the P410s and P660s phases are observed at appropriate trial depths (around 400-500 and 600-700 km, respectively).

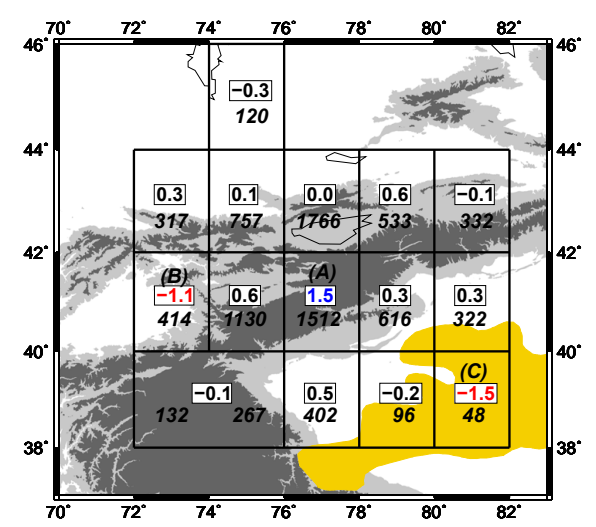

Figure 4. Residuals of the differential time between the P660s and P410s phases in seconds relative to the IASP91. Strongly anomalous boxes (A, B, C) are in south-central Tien Shan (1.5 s, blue), Fergana Basin $(-1.1 \mathrm{~s}$, red), and Tarim $(-1.5 \mathrm{~s}$, red). Light shading indicates elevations greater than $1500 \mathrm{~m}$, and intermediate shading elevations greater than $3000 \mathrm{~m}$. The number of stacked receiver functions in each box is shown by italics. Permian basalts in Tarim are orange.

$\mathrm{C}$ the anomalies are $+1.3 \pm 0.3$ and $-0.2 \pm 0.3 \mathrm{~s}$ for $\mathrm{P} 410 \mathrm{~s}$ and P660s, respectively. The related anomalies of depth are $+13 \pm 3$ and $-2 \pm 3 \mathrm{~km}$ for the 410 and $660 \mathrm{~km}$ boundaries. In other words, the $410 \mathrm{~km}$ boundary is depressed by $\sim 13 \mathrm{~km}$, whereas the $660 \mathrm{~km}$ boundary is flat.

The increased thickness of the MTZ in A is the effect of an uplift of the $410 \mathrm{~km}$ discontinuity and a depression of the $660 \mathrm{~km}$ discontinuity. This is indicative of a low temperature. The MTZ in A may be cooled by a detached and sinking mantle lithosphere (Kosarev et al., 2018). The thinned MTZ in $\mathrm{B}$ is the effect of a depressed $410 \mathrm{~km}$ discontinuity and a stable $660 \mathrm{~km}$ discontinuity. The depression of the $410 \mathrm{~km}$ discontinuity in $\mathrm{B}$, like in $\mathrm{C}$, may be an effect of a temperature anomaly of about $+100 \mathrm{~K}$. The elevated temperature in $\mathrm{B}$ may be related to a small plume, which is responsible for small-scale basaltic volcanism in the Tien Shan from 72 to $60 \mathrm{Ma}$ (e.g., Sobel and Arnaud, 2000). A possible origin of the anomaly in C (Tarim) is discussed in the next section.

\section{Possible origin of the anomalous MTZ beneath Tarim}

Tarim can be characterized as an Archean craton (Yuan et al., 2004) with a complex evolutional history (Zhang et al., 2013; Deng et al., 2017). In the Permian, basalts with an areal extent of about $200000 \mathrm{~km}^{2}$ erupted in the west of the Tarim basin (Fig. 4). The thickness of basalt reaches $800 \mathrm{~m}$. The age span of the magmatism extends from about 292 to $272 \mathrm{Ma}$ with two peaks at 279 and $289 \mathrm{Ma}$ (Wei et al., 2014). The magmatism is interpreted as plume induced (Zhang et al., 2010; Xu et al., 2014). Evidence for the mantle plume beneath Tarim includes the large volume of Permian mafic rocks, OIB-like trace element signatures, Permian crustal doming, and high zircon saturation temperatures (Zhang et al., 2008, 2010). No magmatic activity in this region is known after the Permian (Zhang et al., 2013; Deng et al., 2017).

Figure 4 demonstrates a striking spatial correlation of the depressed $410 \mathrm{~km}$ discontinuity and the Permian magmatic province in Tarim, and we infer a relation between them. An alternative interpretation suggests that the topography on the $410 \mathrm{~km}$ discontinuity, though spatially correlated with the Permian basalts, is caused by another relatively young plume. However, this seems unlikely, as recently erupted (post-Permian) basalts are unknown in this region. Tomographic mantle models for the Tien Shan (Lei and Zhao, 2007; Li et al., 2009; Zabelina et al., 2013) are still not detailed enough to resolve this issue.

Mantle upwelling and the related magmatism can be associated with subduction. For instance, Tang et al. (2014) proposed that Changbaishan volcanism in northeast China is linked to subduction-induced mantle upwelling, which may result in a thinned MTZ. In the Tien Shan there are indications of two subduction zones in the Paleozoic time (Windley et al., 1990). The older Devonian suture in the south marks accretion of the southern passive margin and subduction to the north. The younger late Carboniferous accretion in the northern Tien Shan took place by southward subduction. The time and location of these episodes of subduction are hardly suitable for explaining the Permian magmatism in Tarim. Moreover, even if the Permian basalts in Tarim were somehow subduction related, this would not invalidate the idea of a relation between the Permian basalts and the presently observed thinned transition zone. 
The assumed causal relation between the Permian basalts and the present day anomaly implies that the anomaly at a depth of $\sim 400 \mathrm{~km}$ may exist for $\sim 300$ Myr. To check this possibility we calculated the temperature for a 1-D conductive medium by using a simple heat diffusion expression (e.g., Zharkov et al., 1969) $T(r, t)=\exp \left(-r^{2} / 4 \alpha t\right) / 2 \sqrt{\pi \alpha} t$, where $T$ is temperature, $t$ is time, $r$ is distance, $\alpha$ is thermal diffusivity, and the initial temperature anomaly distribution is taken in the form of a $\delta$ function at $r=0$ and $t=0$. The thermal diffusivity $\alpha$ is taken equal to $32 \mathrm{~km}^{2}$ million $\mathrm{yr}^{-1}$ (e.g., Morgan and Sass, 1984). The results (Fig. 5a) demonstrate that the temperature anomaly in the time interval of 300 million years (between 100 and 400 million years) is halved. The maximum temperature anomaly in plumes is $\sim 300 \pm$ $100^{\circ} \mathrm{C}$ (Campbell, 2005), which means that the temperature anomaly after 300 million years may be around $150^{\circ} \mathrm{C}$, close to the seismic estimate (Kosarev et al., 2018). A comparable result is obtained for a 2-D conductive medium (Fig. 5b). These calculations suggest that the thermal anomaly at a depth of $400 \mathrm{~km}$ may survive for a few hundred million years.

It is also possible that the anomalous depth of the $410 \mathrm{~km}$ discontinuity is an effect of anomalous composition. The pressure of the phase transition in $(\mathrm{Mg}, \mathrm{Fe})_{2} \mathrm{SiO}_{4}$ depends on the $\mathrm{Mg}$ content (Mg no.) relative to $\mathrm{Fe}$ (Fei and Bertka, 1999). Increasing Mg no. from 89 to 92 results in up to $10 \mathrm{~km}$ deepening of the $410 \mathrm{~km}$ discontinuity (Schmerr and Garnero, 2007). The depleted composition and increased Mg no. are commonly interpreted as effects of melting (e.g., Boyd, 1989).

Relative positions of the present day anomaly in the MTZ and the Permian basalt eruptions depend on plate motions in the last $\sim 300 \mathrm{Myr}$. The motions of Tarim are constrained by paleomagnetic data (Zhao et al., 1996). Tarim might have been attached to Eurasia since the late Paleozoic time, but relative motions between Eurasia-Siberia and Tarim continued in the Mesozoic. A $30^{\circ}$ counterclockwise rotation of Tarim with respect to Eurasia can account for the difference between their Permian and Triassic Euler rotation poles. This implies a left lateral strike-slip displacement of $1400 \mathrm{~km}$ for Tarim relative to Eurasia along the southern margin of Kazakhstan. Tarim moved northeast even after the Cretaceous, but estimates of the length of this path are uncertain, and we take $1400 \mathrm{~km}$ for the minimum estimate of motion since the Permian time. As the motion of Eurasia is very slow (Torsvik et al., 2008) this can be taken for the absolute plate motion.

The spatial correlation between the anomaly at a depth of $\sim 400 \mathrm{~km}$ and the basalt eruptions in Tarim (Fig. 4) in spite of the motion of the Tarim craton to the northeast by 1000 $2000 \mathrm{~km}$ is possible if the tectosphere, which translates coherently with the plate, reaches the top of the MTZ.

The difference in viscosity between the lithosphere and asthenosphere suggests that the lithosphere and the underlying mantle are decoupled at the LAB at a depth of $200 \mathrm{~km}$ (Eaton et al., 2009). This is hard to reconcile with the presence of a deep tectosphere. However, the calculations
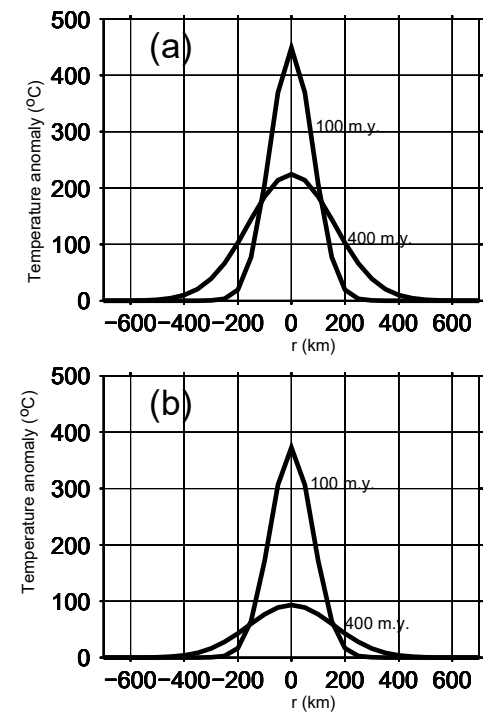

Figure 5. Temperature anomaly distributions in 1-D (a) and 2-D (b) conductive media with an interval of 300 million years.

(Conrad and Lithgou-Bertelloni, 2006) indicate that the lowviscosity asthenosphere is important only if $>100 \mathrm{~km}$ thick. Moreover, lateral viscosity variations or topography on the LAB may increase plate-mantle coupling by a factor of 5 . In fact, coupling between the lithosphere and the underlying mantle is necessary if, as is often accepted, the plates are driven by mantle flow. Qualitatively this is consistent with our observations. The $660 \mathrm{~km}$ discontinuity may be flat in C because the depth range of this discontinuity is outside the tectosphere.

Alternatively, the correlation between the Permian basalts in Tarim and the anomaly of the $410 \mathrm{~km}$ discontinuity is possible without recourse to the deep tectosphere if the paleoreconstructions for Asia are too rough and the actual shift of Tarim is less than predicted by an order of magnitude. This may also be true for the Siberian traps.

\section{Conclusions}

The striking spatial coincidence of the Permian basalts and a depression on the $410 \mathrm{~km}$ discontinuity beneath Tarim (Fig. 4) suggest that both may be related to the same mantle plume. This relation allows a dual interpretation. Some reconstructions suggest a shift of Tarim of more than $1400 \mathrm{~km}$ with respect to Eurasia in the past $300 \mathrm{Myr}$. This can be taken for the absolute plate motion. Then the observed relation between the deep and shallow features can be explained by a coherent translation of the crust and mantle to a depth of $>400 \mathrm{~km}$. Alternatively, the spatial coincidence of the deep and shallow features is possible without recourse to the deep tectosphere if the actual shift of Tarim is less than predicted by the reconstructions by an order of magnitude. Practically, 
similar conclusions would apply to the traps of the Siberian craton.

It would be useful in the future to find other evidence that may indicate whether the tectosphere extends to over $400 \mathrm{~km}$ of depth. This will require further detailed studies of the MTZ. It would be interesting to look at the strength and direction of azimuthal anisotropy in the $100-400 \mathrm{~km}$ depth range. At present the lack of seismograph stations in Tarim makes this impossible.

Data availability. All seismic records can be obtained from IRIS DMC. The stacked $\mathrm{P}$ receiver functions could be downloaded from https://www.researchgate.net/publication/328354055_ stacked_P_receiver_functions (last access: 18 October 2018).

Author contributions. LV proposed the idea and wrote the draft of the paper. YD collected and summarized the data on the geology and tectonics of Tarim. GK, SO, and LM processed the seismic data.

Competing interests. The authors declare that they have no conflict of interest.

Acknowledgements. The waveform data in this study were obtained from Incorporated Research Institutions for Seismology (IRIS). This study was supported by the Strategic Priority Research Program (B) of the Chinese Academy of Sciences (grant XDB18000000), the joint project between the Russian Foundation for Basic Research (RFBR, grant 17-55-53117) and the National Natural Science Foundation of China (NSFC, grants 41611530695 , 41504069). The authors appreciate comments from Rob Porritt, Jennifer Jenkins, and an anonymous reviewer.

Edited by: Caroline Beghein

Reviewed by: Rob Porritt, Jennifer Jenkins, and one anonymous referee

\section{References}

Artemieva, I. M. and Mooney, W. D.: Thermal thickness and evolution of Precambrian lithosphere: a global study, J. Geophys. Res.-Sol. Ea., 106, 16387-16414, 2001

Boyd, F. R.: Compositional distinction between oceanic and cratonic lithosphere, Earth Planet. Sc. Lett., 96, 15-26, 1989.

Bullen, M. E., Burbank, D. W., Garver, J. I., and Abdrakhmatov, K. Y.: Late Cenozoic tectonic evolution of the northwestern Tien Shan: New age estimates for the initiation of mountain building, Geol. Soc. Am. Bull., 113, 1544-1559, 2001.

Campbell, I. H.: Large igneous provinces and the mantle plume hypothesis, Elements, 1, 265-269, 2005.

Conrad, C. P. and Lithgow-Bertelloni, C.: Influence of continental roots and asthenosphere on plate-mantle coupling, Geophys. Res. Lett., 33, L05312, https://doi.org/10.1029/2005GL025621, 2006.
Deng, Y., Levandowski, W., and Kusky, T.: Lithospheric density structure beneath the Tarim basin and surroundings, northwestern China, from the joint inversion of gravity and topography, Earth Planet. Sc. Lett., 460, 244-254, 2017.

Eaton, D. W., Darbyshire, F., Evans, R. L., Grütter, H., Jones, A. G., and Yuan, X.: The elusive lithosphere-asthenosphere boundary (LAB) beneath cratons, Lithos, 109, 1-22, 2009.

Efron, B. and Tibshirani, R.: Statistical data analysis in the computer age, Science, 253, 390-395, 1991.

Fedorenko, V. A., Lightfoot, P. C., Naldrett, A. J., Czamanske, G. K., Hawkesworth, C. J., Wooden, J. L., and Ebel, D. S.: Petrogenesis of the flood-basalt sequence at Noril'sk, north central Siberia, Int. Geol. Rev., 38, 99-135, 1996.

Fei, Y. and Bertka, C. M.: Phase transitions in the Earth's mantle and mantle mineralogy, Mantle petrology: field observations and high pressure experimentation, 6, 189-207, 1999.

Hier-Majumder, S. and Courtier, A.: Seismic signature of small melt fraction atop the transition zone, Earth Planet. Sc. Lett., 308, 334-342, 2011.

Jordan, T. H.: Composition and development of the continental tectosphere, Nature, 274, 544-548, 1978.

Kennett, B. L. N. and Engdahl, E. R.: Traveltimes for global earthquake location and phase identification, Geophys. J. Int., 105, 429-465, 1991.

Keshav, S., Gudfinnsson, G. H., and Presnall, D. C.: Melting phase relations of simplified carbonated peridotite at $12-26 \mathrm{GPa}$ in the systems $\mathrm{CaO}-\mathrm{MgO}-\mathrm{SiO}_{2}-\mathrm{CO}_{2}$ and $\mathrm{CaO}-\mathrm{MgO}-\mathrm{Al}_{2} \mathrm{O}_{3}-\mathrm{SiO}_{2}-$ $\mathrm{CO}_{2}$ : highly calcic magmas in the transition zone of the Earth, J. Petrol., 52, 2265-2291, 2011.

Kosarev, G., Oreshin, S., Vinnik, L., and Makeyeva, L.: Mantle transition zone beneath the central Tien Shan: Lithospheric delamination and mantle plumes, Tectonophysics, 723, 172-177, 2018.

Kraft, H. A., Vinnik, L., and Thybo, H.: Mantle transition zone beneath central-eastern Greenland: Possible evidence for a deep tectosphere from receiver functions, Tectonophysics, 728, 34-40, 2018.

Lei, J. and Zhao, D.: Teleseismic P-wave tomography and the upper mantle structure of the central Tien Shan orogenic belt, Phys. Earth Planet. In., 162, 165-185, 2007.

Li, Z., Roecker, S., Li, Z., Wei, B., Wang, H., Schelochkov, G., and Bragin, V.: Tomographic image of the crust and upper mantle beneath the western Tien Shan from the MANAS broadband deployment: Possible evidence for lithospheric delamination, Tectonophysics, 477, 49-57, 2009.

Molnar P. and Tapponnier P.: Cenozoic tectonics of Asia: effects of a continental collision, Science, 189, 419-426, 1975.

Morgan, P. and Sass, S.: Thermal regime of the continental lithosphere, J. Geodyn., 1, 143-166, 1984.

Reigber, C., Michel, G., Galas, R., Angermann, D., Klotz, J., Chen, J., Papschev, A., Arslanov, R., Tzurkov, V., and Ishanov, M.: New space geodetic constraints on the distribution of deformation in Central Asia, Earth Planet. Sc. Lett., 191, 157-165, 2001.

Schmerr, N. and Garnero, E. J.: Upper mantle discontinuity topography from thermal and chemical heterogeneity, Science, 318, 623-626, 2007.

Shen, Y., Solomon, S. C., Bjarnason, I. T., Nolet, G., Morgan, W. J., Allen, R. M., Vogfjörd, K., Jakobsdóttir, S., Stefánsson, R., Julian, B. R., and Foulger, G. R.: Seismic evidence for a tilted man- 
tle plume and north-south mantle flow beneath Iceland, Earth Planet. Sc. Lett., 197, 261-272, 2002.

Sobel, E. R. and Arnaud, N.: Cretaceous-Paleogene basaltic rocks of the Tuyon basin, NW China and the Kyrgyz Tian Shan: the trace of a small plume, Lithos, 50, 191-215, 2000.

Sobel, E. R. and Dumitru, T. A.: Thrusting and exhumation around the margins of the western Tarim basin during the India-Asia collision, J. Geophys. Res.-Sol. Ea., 102, 5043-5063, 1997.

Tang, Y., Obayashi, M., Niu, F., Grand, S. P., Chen, Y. J., Kawakatsu, H., Tanaka, S., Ning, J., and Ni, J. F.: Changbaishan volcanism in northeast China linked to subduction-induced mantle upwelling, Nat. Geosci., 7.6, 470-475, 2014.

Torsvik, T. H., Steinberger, B., Cocks, L. R. M., and Burke, K.: Longitude: linking Earth's ancient surface to its deep interior, Earth Planet. Sc. Lett., 276, 273-282, 2008.

Vinnik, L. and Farra, V.: Low S velocity atop the $410 \mathrm{~km}$ discontinuity and mantle plumes, Earth Planet. Sc. Lett., 262, 398-412, 2007.

Vinnik, L., Silveira, G., Kiselev, S., Farra, V., Weber, M., and Stutzmann, E.: Cape Verde hotspot from the upper crust to the top of the lower mantle, Earth Planet. Sc. Lett., 319, 259-268, 2012.

Vinnik, L. P., Oreshin, S. I., and Makeyeva, L. I.: Siberian traps: Hypotheses and seismology data, Izv.-Phys. Solid Eart.+, 53, 332340, 2017

Wei, X., Xu, Y.-G., Feng, Y.-X., and Zhao, J.-X.: Plume-lithosphere interaction in the generation of the Tarim large igneous province, NW China: geochronological and geochemical constraints, Am. J. Sci., 314, 314-356, 2014.

Windley, B. F., Allen, M. B., Zhang, C., Zhao, Z. Y., and Wang, G. R.: Paleozoic accretion and Cenozoic redeformation of the Chinese Tien Shan range, central Asia, Geology, 18, 128-131, 1990.
Xu, Y.-G., Wei, X., Luo, Z.-Y., Liu, H.-Q., and Cao, J.: The Early Permian Tarim Large Igneous Province: main characteristics and a plume incubation model, Lithos, 204, 20-35, 2014.

Yuan, C., Sun, M., Yang, J., Zhou, H., and Zhou, M.-F.: Nbdepleted, continental rift-related Akaz metavolcanic rocks (West Kunlun): implication for the rifting of the Tarim Craton from Gondwana, Geol. Soc. Spec. Publ., 226, 131-143, 2004.

Zabelina, I. V., Koulakov, I. Y., and Buslov, M. M.: Deep mechanisms in the Kyrgyz Tien Shan orogen (from results of seismic tomography), Russ. Geol. Geophys.+, 54, 695-706, 2013.

Zhang, C., Li, X., Li, Z., Ye, H., and Li, C.: A permian layered intrusive complex in the western Tarim block, northwestern China: Product of a Ca. 275-ma mantle plume?, J. Geol., 116, 269-287, 2008.

Zhang, C.-L., Xu, Y.-G., Li, Z.-X., Wang, H.-Y., and Ye, H.-M.: Diverse Permian magmatism in the Tarim Block, NW China: Genetically linked to the Permian Tarim mantle plume?, Lithos, 119, 537-552, 2010.

Zhang, C.-L., Zou, H.-B., Li, H.-K., and Wang, H.-Y.: Tectonic framework and evolution of the Tarim Block in NW China, Gondwana Res., 23, 1306-1315, 2013.

Zhao, X., Coe, R. S., Gilder, S. A., and Frost, G. M.: Paleomagnetic constraints on the palaeogeography of China: implications for Gondwanaland, Aust. J. Earth Sci., 43, 643-672, 1996.

Zharkov, V. N., Pan'kov, V. L., Kalachnikov, A. A., and Osnach, A. I.: Introduction in the physics of the Moon, Nauka, Moscow, Russia, 1969 (in Russian). 